\title{
Nisin and $\varepsilon$-poly-L-lysine as natural antimicrobials towards spoilage-associated Lactobacillus plantarum
}

\author{
Fernanda Cristina Kandalski Bortolotto ${ }^{1}$ (i) Maria Helena da Rosa Farfan $^{1}$ (i) \\ Nathalia Cristina Kleinke Jede ${ }^{1}$ (D) Gabriela Maia Danielski ${ }^{1}$ (i) Renata Ernlund Freitas de Macedo $^{1^{*}}$ (D)
}

'Programa de Pós-Graduação em Ciência Animal, Escola de Ciências da Vida, Pontifícia Universidade Católica do Paraná (PUCPR), 80215901, Curitiba, PR, Brasil. E-mail: renata.macedo@pucpr.br. *Corresponding author.

\begin{abstract}
Sausages are highly susceptible to microbial spoilage. Lactic acid bacteria (LAB) is the main group of spoilage bacteria in vacuum packed cooked sausages. To control microbial growth natural antimicrobials have been used as food preservatives. The aim of this study was to identify strains of lactic acid bacteria isolated from spoiled commercial Calabresa sausages and use them in an in vitro challenge with the natural antimicrobials, nisin (NI) and $\varepsilon-p o l y-L-l y s i n e ~(\varepsilon-P L)$. Mass spectrometry identification of LAB isolated from sausages using $M A L D I-T O F$ revealed a predominance of $L$. plantarum in the $L A B$ population. RAPD-PCR of $L$. plantarum strains showed four different genetic profiles. Minimal inhibitory concentration (MIC) and minimal bactericidal concentration (MBC) of NI and $\varepsilon-P L$, alone and in combination, against a pool of different profiles L. plantarum were determined. MIC of NI and $\varepsilon-P L$ were $0.468 \mathrm{mg} / \mathrm{L}$ and $75 \mathrm{mg} / \mathrm{L}$; respectively, whereas $M B C$ of $N I$ and $\varepsilon-P L$ were $12.48 \mathrm{mg} / L$ and $150 \mathrm{mg} / L$, respectively. The combined effect of $N I$ and $\varepsilon-P L$ was determined using concentrations at 1/4 and 1/8 of individual MICs. Synergistic effect was confirmed at both concentrations showing a fractional inhibitory concentration index of 0.5 and 0.2 , respectively. The combination of $N I$ and $\varepsilon-P L$ at a small concentration of $0.05 \mathrm{mg} / L$ and $9.375 \mathrm{mg} / L$, respectively, showed inhibitory effect towards spoilage L. plantarum Results show the potential of the combined use of NI and $\varepsilon$-PL to control sausage spoilageassociated with lactobacilli.
\end{abstract}

Key words: meat product, lactic acid bacteria, natural antimicrobials, shelf life.

Combinação de nisina e $\varepsilon$-poly-L-lysina como antimicrobianos naturais contra Lactobacillus plantarum associado à deterioração

RESUMO: Linguiças são altamente susceptíveis à deterioração microbiana. As bactérias ácido lácticas (BAL) são o principal grupo de bactérias deteriorantes em linguiças cozidas embaladas a vácuo. Para controlar o crescimento microbiano, antimicrobianos naturais têm sido utilizados como conservantes de alimentos. O objetivo deste estudo foi identificar cepas de bactérias ácido lácticas isoladas de linguiças Calabresa em deterioração e utilizá-las como modelo in vitro com os antimicrobianos naturais nisina (NI) e $\varepsilon$-poly-L-lysina ( $\varepsilon$-PL). A identificação por espectrometria de massa das BAL isoladas das linguiças usando a técnica de MALDI-TOF revelou predominância de L. plantarum. A PCR-RAPD revelou quatro perfis genéticos diferentes. A concentração inibitória mínima (CIM) e a concentração bactericida mínima (CBM) de NI e $\varepsilon-P L$, individualmente e em combinação, contra o pool de L. plantarum foram determinadas. $O$ valor de CIM de $N I$ e $\varepsilon$-PL foi $0,468 \mathrm{mg} / \mathrm{L}$ e $75 \mathrm{mg} / \mathrm{L}$, respectivamente, e de CBM de $\mathrm{NI}$ e $\varepsilon-P L$ foi $12,48 \mathrm{mg} / \mathrm{L}$ e $150 \mathrm{mg} / \mathrm{L}$, respectivamente. $O$ efeito da combinação de NI e \&-PL foi determinada usando concentrações de 1/4 e 1/8 dos CIMs individuais. O efeito sinérgico foi confirmado em ambas concentrações mostrando um índice de concentração inibitório fracionado de 0,5 e 0,2, respectivamente. A combinação de NI e ع-PL em baixa concentração, 0,05 mg/L e 9,375 mg/L, respectivamente, mostrou efeito inibitório contra L. plantarum. Os resultados demonstram o potencial do uso combinado de NI e E-PL para o controle de lactobacilos associados à deterioração em linguiça.

Palavras-chave: produto cárneo, bactérias ácido-lácticas, antimicrobianos naturais, vida útil.

\section{INTRODUCTION}

Sausages represent an important segment in the processed meat market worldwide. Calabresa sausage is a cooked sausage widely incorporated in the Brazilian diet. It is one of the main ingredients of the Brazilian traditional dish Feijoada and the Calabresa pizza.
Despite undergoing a cooking process, which reduces the microbial load of cooked meat products, some groups of bacteria, mainly LAB, are able to survive this process, remaining viable in the final product. The microbial deterioration of this type of product is favored by its characteristics as high-water content, $\mathrm{pH}$ (6.6-6.8) and nutritional composition (FORSYTHE, 2013). In vacuum-packed meat 
products, non-putrefactive LAB is the most important group associated with spoilage (HOLLEY \& GILL, 2005; NYCHAS et al., 2008).

A common practice in many retailers of vacuum-packed cooked meat products in Brazil is the storage at room temperature, which leads to the reduction of the shelf life and the onset of signs of spoilage even before the expiration date.

Following the trend of using natural antimicrobials to control microbial growth in food, bacteriocins such as nisin have been applied for controlling a broad spectrum of Gram-positive bacteria, LAB and also sporogenic Bacillus and Clostridium (RILEY \& WERTZ, 2002; CLEVELAND et al., 2001; LERAYER et al., 2015; COTTER et al., 2005). Its effect can be potentiated in combination with organic acids or other natural preservatives (ARAUZ et al., 2009).

$\varepsilon$-poly-L-lysine ( $\varepsilon$-PL) is a cationic peptide composed of 25-35 L-lysine residues, produced by Streptomyces albulus lysinopolymerus and used as a food preservative in Japan, Korea, the United States, and China (SHIH et al., 2006). $\varepsilon$-PL can interact with cell membrane phospholipid heads, causing conformational changes in membrane and forming free vesicles or micelles, leaves a gap through which $\varepsilon$-PL can access cytoplasm and cause even more damage to the cell (HYLDGAARD et al., 2014; NAJJAR et al., 2007).

The synergistic effect of NI associated with $\varepsilon$-PL against some Gram-positive pathogens was reported (NAJJAR et al., 2007; LIU et al., 2015). However, the inhibitory effect of these antimicrobials towards spoilage-associated LAB has not been assessed.

The aim of this study was to identity LAB strains isolated from commercial Calabresa sausage, stored at room temperature and presenting signs of lactic spoilage, and, thereafter, evaluate the antimicrobial effect of NI and $\varepsilon$-PL, individually and in combination, towards these LAB strains.

\section{MATERIALS AND METHODS}

\section{Materials}

Nisin Z (NI 2.5\%; 1,045 IU/ mg) and $\varepsilon$-poly-L-lysine $(99.5 \%)$ were purchased from Handary Ltd (Brussels, Belgium).

\section{Isolation of $L A B$ and phenotypic characterization}

LAB strains were isolated from Calabresa sausages from nine different batches produced by a medium scale processing facility in Brazil, collected in three different retailers. Samples were packaged under vacuum and stored at retail at room temperature.
Samples were collected within 20 to $60 \mathrm{~d}$ of shelf life and presented visual signs of spoilage (slime, presence of exudate and loss of vacuum). Lactic spoilage was confirmed in laboratory by measuring samples pH (digital pHmeter Model HI 99163, Hanna, Portugal), and counting LAB population on MRS agar (ACUMEDIA, Lansing, USA). The $\mathrm{pH}$ of samples ranged from 5.23 to 6.0, (below the normal pH 6.6 for cooked sausage), whereas LAB count varied from 5.86 to $8.30 \log \mathrm{CFU} / \mathrm{g}$.

To isolate the dominant microbiota of LAB from sausages, samples (25 g) were aseptically transferred to sterile plastic bags containing $225 \mathrm{~mL}$ of $0.1 \%$ peptone water (HIMEDIA, Mumbai, India) and homogenized in a stomacher (IUL Instruments, Barcelona, Spain). From the first dilution (1:10), subsequent dilutions were performed and plated in MRS agar (ACUMEDIA, Lansing, USA) plates incubated at $37{ }^{\circ} \mathrm{C}$ for $48 \mathrm{~h}$ under restricted oxygen conditions (Anaerocult, MERCK, Germany). Colonies were counted and $10 \%$ of the colonies were picked up from the highest dilution of agar medium and subjected to cell morphology, Gram staining and catalase activity. One presumptive LAB strain (Gram-positive, catalasenegative, non-motile rods) from each sausage sample was selected for spectrometric identification (MALDITOF) and molecular analysis (RAPD-PCR).

Identification of LAB using MALDI-TOF (matrixassisted laser desorption ionization-time of flight) mass spectrometry

Identification by MALDI-TOF was performed in duplicate by using a VITEK ${ }^{\circledR}$ MS Spectrometer (bioMérieux, Marcy l'Etoile, France). Strains of LAB were grown on trypticase soy agar with $5 \%$ sheep blood (bioMérieux) at $37{ }^{\circ} \mathrm{C}$ for 48 hours. A thin layer of colony growth was applied directly to the target slide using a $1 \mu \mathrm{L}$ loop. Two spots on the target plate were inoculated for each isolate tested with VITEK $^{\circledR}$ MS. The spots were overlaid with 1 $\mu \mathrm{L}$ matrix solution ( $\alpha$-cyano-4-hydroxycinnamic acid; bioMérieux) and allowed to dry before mass spectrometry analysis. The double spotting for the VITEK $^{\circledR}$ MS was required for the algorithm used by the Durham research laboratory to interpret the output of the SARAMIS database (version 3.62). The result was considered acceptable when the confidence score was greater than $90 \%$ for the first spot and the second spot result agreed with the first. Escherichia coli ATCC ${ }^{\circledR} 8739^{\mathrm{TM}}$ was used for every acquisition group on the target slide to calibrate the mass spectrometer. Matrix solution without micro-organisms was used as the negative control. 


\section{DNA extraction of $L A B$}

For the determination of the genetic profile of the Lactobacillus strains, previously identified using MALDI-TOF, bacterial DNA was extracted according to NEUMANN \& POSPIECH (1995). $2 \mathrm{~mL}$ of MRS broth containing each strain grown overnight at $37{ }^{\circ} \mathrm{C}$ were centrifuged for $10 \mathrm{~min}$ at $3,000 \mathrm{~g}$. Cell pellets were resuspended in $500 \mu \mathrm{L}$ of extraction buffer (SET) $(75 \mathrm{mM} \mathrm{NaCl}, 25 \mathrm{mM}$ EDTA, $20 \mathrm{mM}$ Tris $\mathrm{pH} 7.5)$ and lysozyme (1 mg/ $\mathrm{mL})$ and incubated at $37{ }^{\circ} \mathrm{C}$ for $1 \mathrm{~h}$. Then $75 \mu \mathrm{L}$ of $10 \%$ SDS and $0.5 \mathrm{mg} / \mathrm{mL}$ proteinase $\mathrm{K}$ were added and incubated at $55^{\circ} \mathrm{C}$ for $2 \mathrm{~h} .285 \mu \mathrm{L}$ of $\mathrm{NaCl}(5 \mathrm{M})$ and $1 \mathrm{~mL}$ of chloroform were added and incubated at room temperature for $30 \mathrm{~min}$ with frequent inversion. Solution was then centrifuged at $4,500 \mathrm{~g}$ for $15 \mathrm{~min}$ at room temperature, the pellet was discarded and the aqueous phase was transferred to a new tube. An equal volume of ice-cold isopropanol was added to aqueous phase and stored at $-20{ }^{\circ} \mathrm{C}$ overnight. After centrifugation at $4,500 \mathrm{~g}$ for $5 \mathrm{~min}$, pellets were dried at room temperature and resuspended in $100 \mu \mathrm{L}$ of Tris-EDTA buffer + RNAse and stored at $-20{ }^{\circ} \mathrm{C}$ until use. DNA was measured using a NanoDrop 2000 (Thermo Fisher Scientific, Wilmington, MA, USA).

\section{$R A P D-P C R$}

Primer OPA-3 (5'-AGTCAGCCAC-3') was used for RAPD-PCR of $L$. plantarum strains (QUERE et al., 1997). RAPD was performed in a volume of $25 \mu \mathrm{L}$ containing $3 \mathrm{mM} \mathrm{MgCl}, 1$ X Buffer, $0.25 \mathrm{mM}$ Dntp (Invitrogen), 1U Taq (Invitrogen), 3 $\mu \mathrm{M}$ primer and $2 \mu \mathrm{L}$ of resuspended bacterial DNA. RAPD-PCR amplification was performed in a DNA Engine Systems (PTC 200, Bio Rad, Foster City, USA) with initial denaturation at $95{ }^{\circ} \mathrm{C}$ for $5 \mathrm{~min}$, followed by 45 cycles at $94{ }^{\circ} \mathrm{C}$ of $1 \mathrm{~min}, 36^{\circ} \mathrm{C}$ for $1 \mathrm{~min}, 72^{\circ} \mathrm{C}$ for $1 \mathrm{~min}$ and a final extension at 72 ${ }^{\circ} \mathrm{C}$ for $7 \mathrm{~min}$. Amplification products were separated on a $1.5 \%$ agarose gel by $70 \mathrm{~V}$ electrophoresis and stained with ethidium bromide solution. A strain of E. coli $\mathrm{ATCC}^{\circledR} 25922^{\mathrm{TM}}$ was used in each reaction as a positive control.

RAPD banding patterns were analyzed using PyElph 1.4 software (Bio-Rad Laboratories Inc., Hercules, CA, USA). The Dice correlation coefficient was used to calculate similarities in RAPD patterns; dendrograms were obtained by the not weighted pair group method with arithmetic averages (UPGMA). To avoid over representation of clones in the preparation of the inoculum, four strains of Lactobacillus plantarum were selected among those showing different genetic profiles.
Determination of Minimal Inhibitory Concentration (MIC) and Minimum Bactericidal Concentration (MBC)

A pool of four L. plantarum strains, with different genetic profiles, was prepared by inoculating $100 \mu \mathrm{L}$ of each strain at $6 \log \mathrm{CFU} / \mathrm{mL}$, grown in MRS broth for $24 \mathrm{~h}$ at $37^{\circ} \mathrm{C}$, into $7.5 \mathrm{~mL}$ of MRS broth.

The MIC of NI and $\varepsilon$-PL was determined using the tube dilution technique (CLSI, 2018). Treatments were performed in screw-capped tubes containing MRS broth, $80 \mu \mathrm{L}$ of the pool of Lactobacillus spp. and 13 different concentrations of NI, from $0.156 \mathrm{mg} / \mathrm{L}(163.02 \mathrm{IU} / \mathrm{L}=0.16302 \mathrm{IU} /$ $\mathrm{mL})$ to $24.96 \mathrm{mg} / \mathrm{L}(26,083 \mathrm{IU} / \mathrm{L}=26.083 \mathrm{IU} / \mathrm{mL})$ and $\varepsilon$-PL, from $9.3 \mathrm{mg} / \mathrm{L}$ to $150 \mathrm{mg} / \mathrm{L}$. Tubes were incubated at $37^{\circ} \mathrm{C}$ for $24 \mathrm{~h}$. Positive control contained $7.2 \mathrm{~mL}$ MRS broth and $80 \mu \mathrm{L}$ bacterial inoculum. $\varepsilon$-PL negative control contained $6.8 \mathrm{~mL}$ MRS broth and $1.2 \mathrm{~mL} \varepsilon$-PL stock solution $(150 \mathrm{mg} / \mathrm{L})$ and NI negative control contained $7.2 \mathrm{~mL}$ MRS broth and $800 \mu \mathrm{L}$ NI stock solution (26.083 IU/ mL). MIC was defined as the lowest antimicrobial concentration where no increase in turbidity (visible growth) and optical density (600 nm) were observed (CLSI, 2018).

Aliquots $(1.0 \mathrm{~mL})$ from the tubes with no visible growth were pour plated on MRS agar and incubated at $37{ }^{\circ} \mathrm{C}$ for $48 \mathrm{~h}$ in anaerobiosis. $\mathrm{MBC}$ was considered as the lowest antimicrobial concentration where no colony growth was observed after subculture on MRS agar.

\section{Determination of Fractional Inhibitory Concentration Index (ICIF) of NI and $\varepsilon-P L$}

MIC of NI and $\varepsilon$-PL were reduced by $1 / 2$, $1 / 4$ and $1 / 8$ and tested in combination, following the same procedure as previously described. MIC of combination was defined as the lowest antimicrobial concentration where no increase in turbidity (visible growth) and optical density (600 nm) were observed. The type of interaction between NI and $\varepsilon$-PL was evaluated by calculating the Fractional Inhibitory Concentration Index (FICI) (GUTIERREZ et al., 2008). FICI = FIC NI + FIC $\varepsilon$-PL, where FIC NI = MIC NI in combination/ MIC NI and FIC $\varepsilon-\mathrm{PL}=$ MIC $\varepsilon$-PL in combination/ MIC $\varepsilon$-PL.

The interactions between antimicrobials were interpreted as follows: synergistic effect: FICI $<0.5$; additive effect: $0.5 \leq$ FICI $\leq 1$; no interactive effect: $1<\mathrm{FICI} \leq 4$; antagonistic effect: $\mathrm{FICI}>4$.

\section{Statistical Analysis}

Antimicrobial activity assay was conducted in triplicate and results were analyzed by oneway ANOVA with means compared by Tukey test 
$(P<0.05)$ using Statgraphics Centurion XVI v. 16.1.11 (Statpoint Technologies, Warrenton, VA, USA).

\section{RESULTS AND DISCUSSION}

\section{Identification of $L A B$ isolates}

IIdentification of LAB strains using MALDI-TOF revealed eight strains of Lactobacillus plantarum and one strain of L. curvatus. RAPDPCR of these Lactobacillus spp. strains revealed five different patterns corresponding to different strains (Figure 1). Lactobacillus plantarum strains showed four different genetic profiles (clusters I to IV).

Lactobacillus plantarum is a highly heterogeneous species of versatile lactic acid bacteria (LAB), which are reported in many different ecological niches such as vegetables, meat, fish, and dairy products (SIEZEN et al, 2010). Among Lactobacillus spp., L. plantarum usually predominates causing fermentation and spoilage in many types of food, specially at temperatures above $10{ }^{\circ} \mathrm{C}$ (CHOI \& PARK, 2000). High proliferation of LAB results in a large number of metabolic products present in samples such as lactic acid, which lowers $\mathrm{pH}$ of the product and in some species, carbon dioxide, which causes vacuum lost in package. L. plantarum is the species associated with deterioration of cooked meat products packaged under vacuum and kept at room temperature (HOLLEY \& GILL, 2005).

\section{$M I C$ and $M B C$ of $N I$ and $\varepsilon-P L$}

MIC of NI and $\varepsilon$-PL were $0.468 \mathrm{mg} / \mathrm{L}$ $(0.48906 \mathrm{IU} / \mathrm{mL})$ and $75 \mathrm{mg} / \mathrm{L}(75 \mu \mathrm{g} / \mathrm{mL})$, respectively. MBC of NI and $\varepsilon$-PL were $12.48 \mathrm{mg} / \mathrm{L}(13.04 \mathrm{IU} / \mathrm{mL}$ ) and $150 \mathrm{mg} / \mathrm{L}(150 \mu \mathrm{g} / \mathrm{mL})$, respectively (Table 1).

\section{FICI of NI and $\varepsilon-P L$}

Synergistic inhibitory effect of NI and $\varepsilon-\mathrm{PL}$ against $L$. plantarum was observed using combinations of 1/4 and 1/8 of MIC of both compounds (Table 2), showing FIC indices of 0.5 and 0.2 , respectively. FICI is a widely used method for analysis of multiple compound interactions (NAJJAR et al., 2007).

NAJJAR et al. (2007) studied the combination of NI (nisin A) and $\varepsilon$-PL against Grampositive food-borne pathogens Bacillus cereus and Listeria monocytogenes. They reported MIC of NI and $\varepsilon-\mathrm{PL}$ of $300 \mathrm{IU} / \mathrm{mL}$ and $15 \mu \mathrm{g} / \mathrm{mL}$, respectively, for $L$. monocytogenes and a FICI of 0.83 , indicating an additive effect. For Bacillus cereus, they found MIC of $100 \mathrm{IU} / \mathrm{mL} \mathrm{NI}$ and $5 \mu \mathrm{g} / \mathrm{mL} \varepsilon-\mathrm{PL}$; respectively, and a FICI of 0.56 , indicating a synergistic activity. In the present study, the MIC of NI for L. plantarum strains was $0.489 \mathrm{IU} / \mathrm{mL}(0.468 \mathrm{mg} / \mathrm{L})$, showing quite lower values that those reported by the authors. Conversely, the MIC of $\varepsilon$-PL was higher $(75 \mathrm{mg} / \mathrm{L}$ ) than that reported by the authors.

Another Gram-positive species such as Bacillus subtillis (ACCC 10242) and Staphylococcus

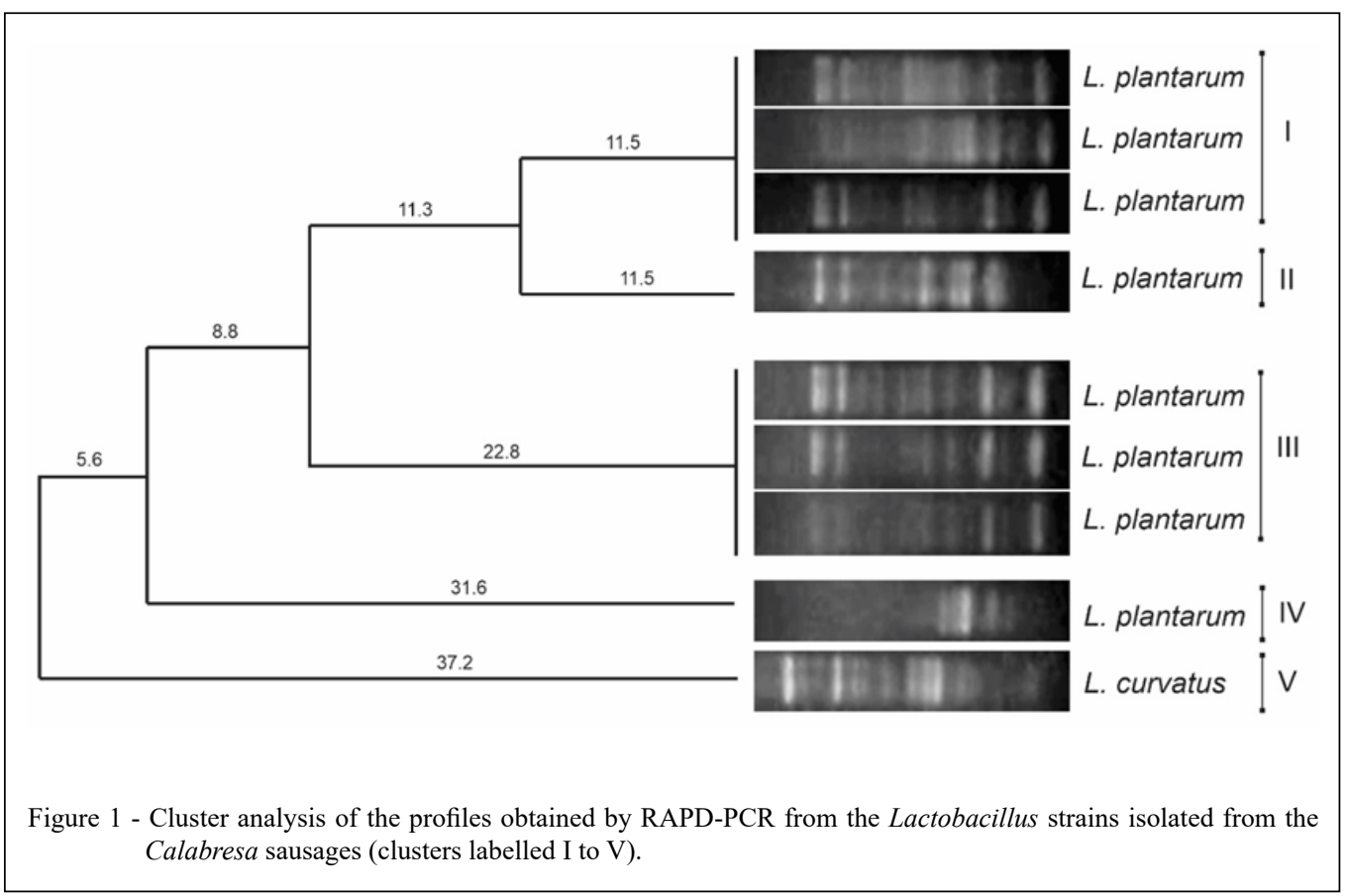

Ciência Rural, v.51, n.2, 2021. 
Table 1 - Results of different concentrations of NI and $\varepsilon$-PL against the pool of Lactobacillus plantarum.

\begin{tabular}{|c|c|c|c|c|c|c|c|}
\hline $\begin{array}{l}\text { Treatment } \\
(\mathrm{mg} / \mathrm{L})\end{array}$ & $\begin{array}{l}\text { Visible } \\
\text { growth }\end{array}$ & $\begin{array}{l}\text { Colony } \\
\text { Growth }\end{array}$ & $\mathrm{DO}_{600 \mathrm{~nm}}(\mathrm{n}=3)$ & $\begin{array}{c}\text { Treatment } \\
(\mathrm{mg} / \mathrm{L})\end{array}$ & $\begin{array}{l}\text { Visible } \\
\text { growth }\end{array}$ & $\begin{array}{l}\text { Colony } \\
\text { Growth }\end{array}$ & $\mathrm{DO}_{600 \mathrm{~nm}}(\mathrm{n}=3)$ \\
\hline $\mathrm{C}+$ & Yes & ND & $1.46 \pm 0.00^{\mathrm{a}}$ & $\mathrm{C}+$ & Yes & ND & $1.32 \pm 0.01^{\mathrm{a}}$ \\
\hline $\mathrm{C}-$ & No & ND & $0.18 \pm 0.03^{\mathrm{e}}$ & $\mathrm{C}-$ & No & ND & $0.07 \pm 0.00^{\mathrm{c}}$ \\
\hline 0.156 & Yes & ND & ND & 9.3 & Yes & Yes & ND \\
\hline 0.234 & Yes & ND & ND & 12.5 & Yes & Yes & ND \\
\hline 0.312 & Yes & ND & $0.68 \pm 0.02^{b}$ & 15 & Yes & Yes & ND \\
\hline 0.468 & No & Yes & $0.25 \pm 0.00^{\mathrm{cd}}$ & 20 & Yes & Yes & ND \\
\hline 0.624 & No & Yes & $0.24 \pm 0.01^{\mathrm{cd}}$ & 25 & Yes & Yes & ND \\
\hline 0.780 & No & Yes & $0.32 \pm 0.03^{\mathrm{c}}$ & 35 & Yes & Yes & ND \\
\hline 0.936 & No & Yes & $0.32 \pm 0.03^{\mathrm{c}}$ & 50 & Yes & Yes & $1.34 \pm 0.00^{\mathrm{a}}$ \\
\hline 1.56 & No & Yes & ND & 65 & Yes & Yes & $1.06 \pm 0.01^{\mathrm{b}}$ \\
\hline 2.34 & No & Yes & ND & 75 & No & Yes & $0.07 \pm 0.00^{c}$ \\
\hline 3.12 & No & Yes & ND & 85 & No & Yes & $0.08 \pm 0.00^{\mathrm{c}}$ \\
\hline 6.24 & No & Yes & ND & 100 & No & Yes & $0.09 \pm 0.00^{c}$ \\
\hline 12.48 & No & No & ND & 125 & No & Yes & $0.09 \pm 0.00^{\mathrm{c}}$ \\
\hline 24.96 & No & No & ND & 150 & No & No & $0.07 \pm 0.00^{\mathrm{c}}$ \\
\hline
\end{tabular}

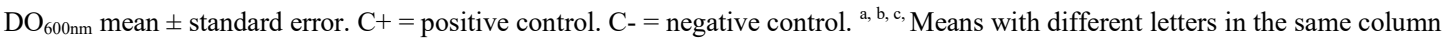
indicate significant differences between treatments $(\mathrm{P}<0.05)$. ND $=$ not determined.

aureus (ACCC 10141) and a Gram-negative E. coli $\left(\mathrm{ATCC}^{\circledR} 25923^{\mathrm{TM}}\right.$ ) were challenged with NI and $\varepsilon$-PL, individually and in combination. MIC of NI ranged from none to $250 \mathrm{mg} / \mathrm{L}$ and MIC of $\varepsilon$-PL varied from $15.63 \mathrm{mg} / \mathrm{L}$ to $62.5 \mathrm{mg} / \mathrm{L}$. FICI ranged from 0.26 to 0.50 (LIU et al., 2015), which was similar to that reported in the present study.

The inhibitory effect of NI towards lactobacilli was reported in strains isolated from kimchi (traditional Korean fermented vegetables) (CHOI \& PARK, 2000). Authors found most of $L$. plantarum strains sensitive to $100 \mathrm{IU} / \mathrm{mL}$, which is the recommended concentration for use in food in many countries.

In Lactobacillus species associated with dental caries (TONG et al, 2010), MIC of NI ranged from $<1,250 \mathrm{IU} / \mathrm{mL}$ to $>625 \mathrm{IU} / \mathrm{mL}$ for L. acidophilus ATCC $^{\circledR} 4356^{\mathrm{TM}},<625 \mathrm{IU} / \mathrm{mL}$ to $>312.5 \mathrm{IU} / \mathrm{mL}$ for L. casei $\mathrm{ATCC}^{\circledR} 393^{\mathrm{TM}}$, and $<78.125 \mathrm{IU} / \mathrm{mL}$ and $>39.0625 \mathrm{IU} / \mathrm{mL}$ for $L$. fermenti $\mathrm{ATCC}^{\circledR} 9338^{\mathrm{TM}}$. $\mathrm{MBC}$ ranges against those strains were $<2,500 \mathrm{IU} /$ $\mathrm{mL}$ and $>1,250 \mathrm{IU} / \mathrm{mL}$ for L. acidophilus; $<1,250 \mathrm{IU} /$ $\mathrm{mL}$ and $>625 \mathrm{IU} / \mathrm{mL}$ for $L$. casei and $<156.25 \mathrm{IU} / \mathrm{mL}$ and $>78.125 \mathrm{IU} / \mathrm{mL}$ for $L$. fermenti.

To our knowledge, the inhibitory effect of $\varepsilon$-PL individually or in combination with NI towards lactobacilli has not been reported until this present study.
Although, most bacteria tested are Grampositive (Listeria sp., Bacillus sp., Staphylococcus sp., Lactobacillus sp.), the resistance to antimicrobials vary among different genera and different species in the same genus. Nisin is a cationic peptide which acts in the cell membrane of bacteria via pores formation to interfere with cell wall biosynthesis (LIU et al, 2015). It recognizes and binds anionic lipids in the target membrane, inducing temporary membrane perturbations and assembling into a pore. Nisin can also interact with high-affinity pyrophosphate binding sites on the membrane bound cell wall precursor lipid II (TONG et al, 2010). The pore formation will result in an efflux of small cytoplasmic compounds or the collapse of vital ion gradients, leading to cell death. The affinity of nisin for lipid II is much higher than the affinity of nisin for membranes containing anionic lipids (BIERBAUM \& SAHL, 2009). The different affinities for cell membranes may explain the different concentrations of NI needed to inhibit different bacteria in the studies reported.

The concentration of antimicrobials to inhibit the target bacteria is also affected by the form of application and the matrix tested because food compounds may interact with antimicrobials and affect their action. Concentration of natural antimicrobials needed to achieve an inhibitory effect 
Table 2 - Effect of the combination of different concentrations of NI and $\varepsilon$-PL against Lactobacillus plantarum.

\begin{tabular}{|c|c|c|c|c|c|}
\hline \multirow[t]{2}{*}{ Treatments } & \multicolumn{2}{|c|}{------Concentration (mg/L)------- } & \multirow[t]{2}{*}{ Visible growth } & \multirow[t]{2}{*}{ FICI } & \multirow[t]{2}{*}{ Effect } \\
\hline & NI & $\varepsilon-\mathrm{PL}$ & & & \\
\hline $1 / 2 \mathrm{MIC} \mathrm{NI}+1 / 2 \mathrm{MIC} \varepsilon-\mathrm{PL}$ & 0.234 & 37.5 & No & 1 & Additive \\
\hline $1 / 4 \mathrm{MIC} \mathrm{NI}+1 / 4 \mathrm{MIC} \varepsilon-\mathrm{PL}$ & 0.117 & 18.75 & No & 0.5 & Synergistic \\
\hline $1 / 8 \mathrm{MIC} \mathrm{NI}+1 / 8 \mathrm{MIC} \varepsilon-\mathrm{PL}$ & 0.050 & 9.375 & No & 0.2 & Synergistic \\
\hline
\end{tabular}

Tests were incubated at $37^{\circ} \mathrm{C}$ for $24 \mathrm{~h}$. FICI $<0.5$ indicates a synergic effect; $0.5 \leq \mathrm{FICI} \leq 1$ represents an additive effect; $1<\mathrm{FICI} \leq 4$ has no interactive effect; and FICI $>4$ indicates an antagonistic effect.

in vitro is usually lower than that in food matrices (HYLDGAARD et al, 2015). Using a solution sprayed on the surface of ready-to-eat seafood (minced tuna and salmon roe) containing NI and $\varepsilon-\mathrm{PL}$, the concentrations to achieve a synergistic effect against L. monocytogenes was $12.5 \mathrm{ppm}$ NI $(500 \mathrm{pm}$ NI compound containing $2.5 \% \mathrm{NI}$ ) and $1,000 \mathrm{ppm} \varepsilon$-PL (2,000 pm $\varepsilon$-PL compound containing 50\% $\varepsilon-\mathrm{PL})$, as reported by Takahashi et al. (2012). Although, the authors have reported the effect of NI $+\varepsilon$-PL in a food matrix, the inhibitory concentration was high. If the in vitro synergistic concentration of $\mathrm{NI}+\varepsilon-\mathrm{PL}$ (IFIC) reported in the present study is increased 100 -fold for future use in a meat product to inhibit lactic spoilage, the concentration of antimicrobials would be $5 \mathrm{ppm}$ $(\mathrm{mg} / \mathrm{kg})$ of NI and $937.50 \mathrm{ppm}(\mathrm{mg} / \mathrm{kg})$ of $\varepsilon$-PL.

The combination of NI and $\varepsilon$-PL synergistically enhance the permeability of the bacterial cell membrane, likely reflecting the inhibition of both $\mathrm{Na}^{+} \mathrm{K}^{+}$and $\mathrm{Ca}^{++} \mathrm{Mg}^{++}$ATPase activities through these compounds. Recent findings indicate that $\varepsilon$-PL can interact to DNA through insertion into the double helix structure, thereby hindering DNA replication. After nisin has damaged the cell structure, $\varepsilon$-PL can easily enter the cells, interacts with DNA, and eventually hinders DNA replication (LIU et al, 2015; LIU et al, 2015).

\section{CONCLUSION}

This study showed the synergistic effect of NI and $\varepsilon$-PL to control spoilage L. plantarum, at low concentrations $(0.05 \mathrm{mg} / \mathrm{L}$ NI and $9.375 \mathrm{mg} / \mathrm{L}$ $\varepsilon$-PL). Therefore, the combination of these natural antimicrobials shows potential to be further used in meat matrices to control lactic acid spoilage bacteria, increasing the shelf life of the product and helping the food industry to offer safer and more sustainable foods to the consumer.

\section{ACKNOWLEDGEMENTS}

This study was financed in part by the Coordenação de Aperfeiçoamento de Pessoal de Nível Superior (CAPES), Brasil - Finance code 001.

\section{DECLARATION OF CONFLICT OF INTERESTS}

The authors declared no potential conflicts of interest with respect to the research, authorship, and/or publication of this article.

\section{AUTHORS' CONTRIBUTIONS}

FCKB and REFM conceived and designed experiments. FCKB, MHRF, NCKJ and GMD performed the experiments and carried out the lab analyses. FCKB and REFM performed statistical analyses of experimental data. FCKB and REFM prepared the draft of the manuscript. All authors critically revised the manuscript and approved the final version.

\section{REFERENCES}

ARAUZ, L. J., et al. Nisin biotechnological production and application: a review. Trends in Food Science and Technology, v.120, p.146-154, 2009. Available from: <https://www. sciencedirect.com/science/article/abs/pii/S0924224409000594>. Accessed Feb. 22, 2019. doi: 10.1016/j.tifs.2009.01.056.

BIERBAUM,G.;SAHL,H.G.Lantibiotics:modeofaction, biosynthesis and bioengineering. Current Pharmaceutical Biotechnology, v.10, p.2-18, 2009. Available from: <https://www.ingentaconnect.com/ content/ben/cpb/2009/00000010/00000001/art00002>. Accessed: Dec. 15,2019 . doi: $10.2174 / 138920109787048616$.

CHOI, M. H.; PARK, Y. H. Selective control of lactobacilli in kimchi with nisin. Letters in Applied Microbiology, v.30, p.173177, 2000. Available from: <https://sfamjournals.onlinelibrary. wiley.com/doi/full/10.1046/j.1472-765x.2000.00719.x>. Accessed: Jun. 14, 2019. doi: 10.1046/j.1472-765x.2000.00719.x.

CLSI, Clinical and Laboratory Standards Institute. Methods for dilution antimicrobial susceptibility tests for bacteria that grow aerobically. 11th. Ed. CLSI standard M07. Wayne, PA (2018).

Ciência Rural, v.51, n.2, 2021. 
Available from: $<$ https://www.researchgate.net/file.PostFileLoader. html?id>. Accessed: Mar. 30, 2018. doi: 610.688.0700www.clsi.org.

CLEVELAND J., et al. Bacteriocins: safe natural antimicrobials for food preservation. International Journal of Food Microbiology, v.71, p.1-20, 2001. Available from: <https://www.sciencedirect. com/science/article/abs/pii/S0168160501005608>. Accessed: Apr 29, 2019. doi: 10.1016/S0168-1605(01)00560-8.

COTTER P. D., et al. Bacteriocins: developing innate immunity for food. Nature Reviews/ Microbiology, v.3, p.773-788, 2005. Available from: <https://www.nature.com/articles/nrmicro1273>. Accessed: Jun. 06, 2018.

FORSYTHE, Stephen, J. Microbiologia da Segurança dos Alimentos. 2 ed. Porto Alegre: Artmed, 2013. p.146-150.

GUTIERREZ J.; et al. The antimicrobial efficacy of plant essential oil combinations and interactions with food ingredients. International Journal of Food Microbiology, v.124, p.91-97, 2008. Available from: <https://www.sciencedirect.com/science/ article/abs/pii/S0168160508001177> Accessed: Sep. 20, 2018. doi: 10.1016/j.ijfoodmicro.2008.02.028.

HOLLEY R.; GILL C. O. Use of modified atmosphere to meat and meat products. Speech. III Congresso Brasileiro de Ciência e Tecnologia de Carnes. 27 - 29, September, 2005.

HYLDGAARD M., et al. The antimicrobial mechanism of action of epsilon-poly-L-lysine. Applied and Environmental Microbiology, v.80 (24), p.7758-7770, 2014. Available from: $<$ https://aem.asm.org/content/80/24/7758.short $>$. Accessed: May, 20, 2018. doi: 10.1128/AEM.02204-14.

HYLDGAARD, M. et al. Binary combination of epsilon-poly-Llysine and isoeugenol affect progression of spoilage microbiota in fresh turkey meat, and delay onset of spoilage in Pseudomonas putida challenged meat. Int J Food Microbiol, v.215, p.131-142, 2015. Available from: $<$ https://www.sciencedirect.com/science/ article/abs/pii/S0168160515301276>. Accessed: Dec. 10, 2019. doi: 10.1016/j.ijfoodmicro.2015.09.014.

LERAYER, A. L. S., et al. Action of nisin on sporogenic bacteria of Bacillus gender. Tecnolat/ ITAL. ITAL Artigos Técnicos. 2015. LIU. H., et al. The antimicrobial effect and synergistic antibacterial mechanism of the combination of $\varepsilon$-Polylysine and Nisin against Bacillus subtilis. Food Control, v.47, p.444-450, 2015. Available from: <https://www.sciencedirect.com/science/article/abs/pii/ S0956713514004356>. Accessed: Jun. 14, 2019. doi: 10.1016/j. foodcont.2014.07.050

LIU, F. et al. Synergistic antibacterial effect of the combination of c-Polylysine and nisin against Enterococcus faecalis. Journal of Food Protection, v.78, p.2200-2206, 2015. Available from: $<$ https:// meridian.allenpress.com/jfp/article-abstract/78/12/2200/174528/ Synergistic-Antibacterial-Effect-of-the?redirectedFrom=fulltext $>$ Accessed: nov. 15,2019. https://doi.org/10.4315/0362-028X.JFP$15-220$.
NAJJAR. M. B., et al. E-Poly-L-lysine and nisin A act synergistically against Gram-positive food borne pathogens Bacillus cereus and Listeria monocytogenes. Letters Applied in Microbiology, v.45, p.8-13, 2007. Available from: < https:// sfamjournals.onlinelibrary.wiley.com/doi/full/10.1111/j.1472765X.2007.02157.x Accessed: Apr. 29, 2019. doi: https://doi. org/10.1111/j.1472-765X.2007.02157.X.

NEUMANN B.; POSPIECH A. A versatile quick-prep of genomic DNA from Gram-positive bacteria. Trends in Genetics, v.11, p.217-218, 1995. Available from: <http://www.sciencedirect.com/ science/article/pii/S0168952500890526>. Accessed: Feb. 22, 2017. doi: 10.1016/S0168-9525(00)89052-6.

NYCHAS, G. J. E., et al. Meat spoilage during distribution. Meat Science, v.78, p.77-89, 2008. Available from: <https://www. sciencedirect.com/science/article/abs/pii/S0309174007002185>. Accessed: Apr. 29, 2019. doi: 10.1016/j.meatsci.2007.06.020.

QUERE. F, et al. DNA probe and PCR-specific reaction for Lactobacillus plantarum. Journal of Applied Microbiology, v.82, p.783-790, 1997. Available from: $<$ https://sfamjournals.onlinelibrary. wiley.com/doi/abs/10.1046/j.1365-2672.1997.00157.x>. Accessed: May, 04, 2018. doi: 10.1046/j.1365-2672.1997.00157.x.

RILEY, M. A.; WERTZ. J. E. Bacteriocin diversity ecological and evolutionary perspectives. Biochemie, v.84, p.57-364, 2002. Available from: $<$ https://www.sciencedirect.com/science/article/ abs/pii/S0300908402014219>. Accessed: May, 20, 2019. doi: 10.1016/S0300-9084(02)01421-9.

SHIH I. L., et al. Microbial synthesis of poly (epsilon-lysine) and its various applications. Bioresource Technology, v.97(9), p.1148-1159, 2006. Available from: <https:/www.sciencedirect. com/science/article/abs/pii/S0960852404003049>. Accessed: Apr. 21, 2019. doi: 10.1016/j.biortech.2004.08.012.

SIEZEN, R. J., et al. Phenotypic and genomic diversity of Lactobacillus plantarum strains isolated from various environmental niches. Environmental Microbiology, v.12 (3), p.758-773, 2010. Available from: $<$ https://sfamjournals.onlinelibrary.wiley.com/doi/ full/10.1111/j.1462-2920.2009.02119.x?casa token=RsMCAAAn TOgAAAAA\%3AppwaQ5S190 0vmoLsp56UD2qHbmqZLR4hn bH7Qi0RNoPJMWJuWP1vbzP-WYaju7au7nyg9ej5XcXmokX>. Accessed: May, 04, 2018. doi: 10.1111/j.1462-2920.2009.02119.x.

TAKAHASHI. H., et al. Effect of paired antimicrobial combinations on L. monocytogenes growth inhibition in readyto-eat seafood products. Food Control, v.26, p.397-400, 2012. Available from: $<$ https://www.sciencedirect.com/science/article/ abs/pii/S0956713512000795>. Accessed: Jun. 14, 2019. doi: 10.1016/j.foodcont.2012.02.005.

TONG, Z., et al. Nisin inhibits dental caries-associated microorganism in vitro. Peptides, v.31, p.2003-2008, 2010. Available from: <https://www.sciencedirect.com/science/article/ abs/pii/S0196978110003281>. Accessed: Jul. 08, 2019. doi: 10.1016/j.peptides.2010.07.016. 